\title{
KIERKEGAARD A FILOZOFICZNE DOWODY NA ISTNIENIE BOGA
}

Co najmniej od czasów św. Augustyna wielu myślicieli podejmowało i podejmuje nadal rozliczne próby czysto racjonalnego wykazania istnienia Boga. U schyłku starożytności europejskiej wraz z narodzinami myśli chrześcijańskiej pojawia się coś, co dziś nazywamy filozofią Boga. Pośród zastępów chrześcijan wierzących w Boga w Trójcy Jedynego, zawsze znajdowali się tacy, którym nie wystarczały prawdy wiary. Dążyli, choćby do częściowego, ich uracjonalnienia, tak aby treść wiary była również dostępna rozumowi. W zdecydowanej większości przypadków dowody na istnienie Boga były dziełem ludzi już uprzednio wierzących w Jego istnienie. $Z$ pewnością tak było u Augustyna, Anzelma, Tomasza, Kartezjusza i u wielu innych. Oczywiście nie chodzi tu tylko o chrześcijan. Platon czy Plotyn nie znali chrześcijańskiego Objawienia, ale przecież nikt, kto wczytał się w Timajosa lub Enneady nie zaprzeczy, że byli to ludzie na swój sposób głęboko wierzący. Lecz jeśli nawet ograniczymy się do chrześcijan, to i tak pozostaje pytanie otwarte, co jest pierwsze: wiara i na niej osadzone głębokie osobiste przekonanie, czy argument filozoficzny, który miałby rodzić doświadczenie nieodpartej oczywistości intelektualnej? Czy też może jest tak, że wiara pociąga za sobą zrozumienie, a zrozumienie buduje wiarę. Nawzajem się warunkują i tworzą swego rodzaju sprzężenie zwrotne. $\mathrm{Na}$ tym tle można postawić bardziej szczegółowe pytania. Jaką wartość mają dziś, w świetle rozbudowanej refleksji filozofii wspólczesnej, dowody na istnienie Boga? W szczególności, jakie znaczenie mają one dla człowieka niewierzącego, który z jednej strony szczerze poszukuje Boga, z drugiej zaś za nic nie chciałby porzucić racjonalnego dyskursu i rygorów logicznego myślenia na rzecz jakiejś przypadkowej „ślepej” wiary. Kwestie te są tym bardziej ważne, że potrzeba przeświadczenia o istnieniu Boga nie sprowadza się do teoretycznego poznania, lecz ma wymiar głębszy, praktyczny, etyczny i egzystencjalny. Zaspokojenie tej potrzeby nie jest nasyceniem próżnej ciekawości, lecz stanowi o jakości duchowego życia człowieka. $Z$ tej racji ewentualna krytyka dowodów na istnienie Boga może być interesująca i mieć swoją wartość, jeśli zosta- 
nie przeprowadzona z pozycji etycznych i egzystencjalnych, a nie teoriopoznawczych.

Przyjrzyjmy się krytyce przynajmniej niektórych rodzajów dowodów na istnienie Boga, pochodzącej od duńskiego egzystencjalisty $\$ \varnothing$ rena Kierkegaarda (1813-1855)*. W odróżnieniu od wielu swoich rówieśników z 1. połowy XIX wieku, Kierkegaard jest myślicielem na wskroś nowoczesnym. Od końca II wojny światowej zainteresowanie jego myślą ciągle wzrasta. Swiadczą o tym wydawane każdego roku dziesiątki (jeśli nie setki) prac w języku duńskim, niemieckim, angielskim, włoskim czy francuskim, w których analizowane i rozwijane są jego pomysły. Kierkegaardiańska filozofia człowieka daje możliwość nowego spojrzenia na istotę religijnego związku egzystującej jednostki ludzkiej z Bogiem. Stwarza nade wszystko możliwości wyraźnego rozgraniczenia między indywidualnym doświadczaniem rzeczywistości Boga, a jakimkolwiek ludzkim przedstawieniem (pojęcie, idea, wyobrażenie) tegoż Boga. Z perspektywy tego rozróżnienia Kierkegaard przeprowadza krytykę niektórych dowodów na istnienie Boga. Ogólny wniosek wypływający z jego krytycznych analiz byłby mniej więcej taki: filozoficzne argumenty na rzecz istnienia Boga, zakładają już u dowodzącego jego osobiste przeświadczenie, że przedmiot dowodzenia istnieje. Kierkegaard pokazuje, że brak takiego przeświadczenia uniemożliwia jakiekolwiek dowodzenie w tej materii. Jest ono zatem zabiegiem wtórnym, mało istotnym, a nierzadko powodującym powstawanie fałszywych mniemań już nie tyle co do istnienia, lecz co do natury Boga. Poparcie tego wniosku znajdujemy w rozbudowanych analizach Okruchów filozoficznych, w Zamykajacym nienaukowym postscriptum oraz w dosyć licznych notatkach Dzienników. Przytoczmy zatem argumentację Kierkegaarda, krytycznie ją zarazem oceniając.

\section{Dowód ontologiczny}

Ontologiczny dowód św. Anzelma z Canterbury stanowi poniekąd punkt wyjścia u Kierkegaarda. Nawiązuje do niego nie wprost, nie wymieniając go z nazwy. W Okruchach filozoficznych czytamy: „O ile Bóg nie istnieje — niemożliwością jest dowiedzenie Jego istnienia, ale jeśli jest, to byłoby głupio chcieć to udowadniać; w tym bowiem momencie, w którym zaczynam dowodzić, założyłem Jego istnienie, i to nie jako wątpliwe (bo wtedy nie mogłoby ono stanowić założenia, a przecież jest założeniem), lecz jako to, co ustalone, gdyż w innym wypadku w ogóle bym nie zaczynał i łatwo zauważyć, że całość

* Częściej cytowane dzieła Kierkegaarda podano w skrócie:

Okruchy - S. Kierkega ard, Okruchy filozoficzne. Chwila, Warszawa 1988.

Papirer - tenże, Papirer, Copehagen 1968 - 1970.

Afsluttende - tenże, Afsluttende uvidenskabelig efterskrift Samlede vaerker, B. 9 - 10, Copenhagen 1962-1964. 
wywodu byłaby bezsensowna, gdyby Jego nie było" 1 . W przytoczonym fragmencie widać od razu, jakiego wstępnego rozstrzygnięcia dokonuje autor Okruchów. Milcząco zakłada, że przedmiot poznania musi uprzednio istnieć niezależnie od poznającego, aby mógł być poznany. Odkrycie istnienia przedmiotu, w tym przypadku Boga, jest odkryciem obiektywnego faktu, nie jest natomiast dedukcyjnym wyprowadzeniem konieczności Jego istnienia. Kierkegaard zaprzecza pośrednio możliwości przejścia od posse do esse, czy, inaczej mówiąc, możliwości wnioskowania z bytu możliwego (np. pomyślanego) o istnieniu bytu realnego.

Jeszcze bardziej zdecydowane potwierdzenie tego stanowiska znajdujemy w Dziennikach. „Chęć wykazania istnienia Boga — pisze Kierkegaard — jest szczytem śmieszności. Bo albo On nie istnieje i wtedy nie można tego dowieść [...] (co najwyżej mogę znaleźć świadectwa, ale i tak zakładam Jego istnienie) - albo Bóg istnieje i wtedy niczego więcej nie da się pokazać" 2 . Wygląda na to, przynajmniej w pierwszym momencie, że Kierkegaard zdecydowanie przekreśla wartość wszystkich tych prób, których nerw rozumowania jest taki sam, jak w dowodzie św. Anzelma. W istocie tak nie jest. Kierkegaard nie obala tego dowodu, nie próbuje nawet pomniejszać jego znaczenia, lecz zwraca uwagę na to, co się często pomija lub niedostatecznie mocno akcentuje u Anzelma. Trzeba bowiem podkreślić, że ten jedenastowieczny scholastyk, wierny swej filozoficznej zasadzie „Fides quaerens intellectum”, przyjmuje w punkcie wyjścia prawdę wiary, która głosi, że Bóg realnie istnieje, po czym szuka jej racjonalnego potwierdzenia. Dana wiara jest niepodważalna, ani na moment nie można od niej abstrahować. Kierkegaard pisze: „Anzelm mówi: chcę dowieść istnienia Boga. W tym celu proszę Boga, aby mnie umocnit i pomógt mi [...]. Lecz to zwrócenie się do Boga jest o wiele lepszym dowodem na Jego istnienie. Oparte jest bowiem na pewności, że bez pomocy Boga nie można wykazać Jego istnienia. Gdyby się to dało uczynić bez pomocy, byłoby jakby mniej pewne, że On istnieje"3. Żarliwość wiary Anzelma przesądza wszystko. Filozoficzny dowód jest w tym kontekście zabiegiem formalnym i wtórnym. Inaczej sprawa wygląda - jak słusznie zauważa Kierkergaard — w przypadku niektórych nowożytnych zwolenników tego dowodu, do których niewątpliwie zaliczyć należy Kartezjusza, Kanta i Hegla. Ich podejście jest zasadniczo różné. Nie rozpoczynają bowiem od przesłanki teologicznej, która jednoznacznie problem rozstrzyga, lecz od mniej lub bardziej niepewnych przesłanek filozoficznych. Stąd też w punkcie wyjścia sprawa istnienia Boga nie jest u nich przesądzona ${ }^{4}$. Wnioski, jakie osiągają mają zgoła odmienną wartość poznawczą niż u Anzelma.

\footnotetext{
1 Okruchy, s. 47.

2 Papirer, V A 7.

${ }^{3}$ Tamże, $\mathrm{X}^{4}$ A 210.

${ }^{4}$ Tamże,
} 


\section{Stabość dowodów ze skończonych przestanek}

Powstaje pytanie: dlaczego przed jakimkolwiek dowodzeniem trzeba przyjąć (założyć) realne istnienie Boga? Sympatia Kierkegaarda do średniowiecznego scholastyka ma bez wątpienia głębsze uzasadnienie i nie jest żadną ,fideistyczną" opcją, jeśli pod tym rozumieć jakąś stricte irracjonalną decyzję wiary. Kierkegaard wskazuje na dwa powody. Jeden z nich ma charakter psychologiczny, drugi ontologiczno-epistemologiczny. W pierwszym przypadku dowodzący, jeśli poprzestanie na własnym rozumie, nigdy nie wyzwoli się z obawy, że to, czego usiłuje dowieść, może nie istnieć. Innymi słowy, nigdy nie zdoła siebie do końca przekonać, czy cała ta racjonalna procedura nie jest tylko intelektualną igraszką, urealniającą płody jego wyobraźni.

Powód drugi ma charakter bardziej obiektywny i daje się wyrazić następująco: nie istnieją takie przesłanki, wzięte ze skończonego świata, które byłyby prawomocnym i niepodważalnym punktem wyjścia w dowodzeniu. Kierkegaard nie rozpatruje tej tezy w tak ogólnym sformułowaniu. Zadawala się szczególnym przypadkiem, który jednak łatwo daje się uogólnić na inne, podobne przypadki. I tak odrzuca wnioskowanie o Bogu z celowości przyrody. „Sama przyroda wynajduje liczne środki odstraszające, stwarza liczne utrudnienia, by temu zamierzeniu przeszkodzić" 5 . W tej lapidarnej wypowiedzi wyraźnie pobrzmiewa sceptycyzm Kanta, wedle którego interpretacje zjawisk świata zmysłowego, jeśli doszukiwać się pod nimi rzeczy samych w sobie, połączonych zgodnie z zasadami powszechnymi, muszą w wyniku dawać antynomie. „Zarówno bowiem danego twierdzenia — pisze Kant — jak i twierdzenia jemu przeciwnego można dowieść przy pomocy jednakowo przekonujących, jasnych i nieodpartych dowodów"6. Kierkegaard niedwuznacznie sugeruje, że za celowością przyrody stoi tyle samo argumentów, co i przeciw niej. Łatwo zauważyć, że w oczach Kierkegaarda nie znalazłaby uznania ani jedna „droga” Tomasza z Akwinu, w szczególności zaś piąty argument: z celowości. Faktycznie Kierkegaard nigdy nie zajmował się wykazywaniem istnienia takich antynomii. Problematyka filozofii przyrody i metafizyki ogólnej była mu najzupełniej obca. Jeśli coś na ten temat wiedział to głównie za sprawą lektury Kanta. Jego opinie, wyrażane zresztą dosyć marginalnie, nie wykraczają poza ducha kantowskiego myślenia.

\section{Namiętność samopoznania źródtem myślenia o Bogu}

Z powyższego wnioskonać należy, że problem istnienia Boga nie jest problemem teoretycznym. Kierkegaard odrzuca czysto redukcyjne rozumowania,

${ }^{5}$ Okruchy, s. 52 n.

${ }^{6}$ I. Ka n t, Prolegomena, Warszawa 1960, s. 136. 
w których przesłanki - ogólne sądy metafizyczne, dotyczące skończonego, ograniczonego w czasie i przestrzeni - miałyby prowadzić do uznania istnienia Pierwszej Przyczyny, Najwyższego Celu itd. Odrzuca nie dlatego, że ma im coś do zarzucenia od strony formalnej, logicznej. Nie bada ich zresztą pod tym kątem. Rezygnuje $\mathrm{z}$ nich, ponieważ nie są odpowiedzią na egzystencjalną potrzebę ducha ludzkiego.

Cała refleksja kierkegaardiańskiej filozofii człowieka obraca się wokół jednej, fundamentalnej potrzeby jednostki ludzkiej. Jest nią potrzeba poznania (czy też rozpoznania) samego siebie. Gdyby ktoś chciał w tym momencie zaprotestować mówiąc, że dałoby się wymienić jeszcze z tuzin innych, równie ważnych potrzeb ludzkich, choćby takich jak: pragnienie własnego szczęścia, pełnego intelektualnego i duchowego rozwoju, życia w miłości itd., nie stałby się przez to adwersarzem Kierkegaarda. Te i inne, niewymienione potrzeby, mają, wedle tego myśliciela, swe zakotwiczenie w samopoznaniu. Ono umożliwia już nie tylko ich słowną artykulację, ale w ogóle ich ujawnienie, uświadomienie, przeżycie. Procesowi samopoznania szczególnie dużo miejsca poświęca Kierkegaard w dwutomowym Albo-albo, gdzie analizuje różne sposoby życia jednostki w stadiach: estetycznym i etycznym. Gruntowniejsze zajęcie się tą problematyką wykraczałoby jednak poza ramy niniejszego artykułu.

Kim jestem? To pytanie Sokratesa jest punktem wyjścia u Kierkegaarda również w refleksji nad istnieniem Boga. Zadanie filozofii jest teraz inne. Kierkegaard obiera nową, nieznaną dotąd w filozofii nowożytnej, metodę, której celem jest pomoc konkretnej jednostce w jej samopoznaniu. Wychodzi się tutaj z założenia, że to, co bezpośrednio dotyczy człowieka, głównie pod postacią wiedzy o nim samym, nie może być darem (bezpośrednim przekazem) pochodzącym od drugiego. Tę istotną dla siebie wiedzę (o cechach swej osobowości, życiu w wymiarze etycznym i religijnym) musi człowiek sam z siebie wydobyć. Drugi człowiek może mu w tym pomóc, zajmując wobec niego postawę Sokratesa, greckiego majeuty. Filozofia Kierkegaarda w zamyśle, jak i chyba w realizacji (rzecz wymagałaby solidnego zbadania), jest takim majeutycznym podprowadzeniem czytelnika w kierunku samopoznania, jest sugerowaniem, a nie narzucaniem sposobów życia. Nie dostarcza przy tym jakichś nowych, spekulatywnych rozwiązań problemu natury ludzkiej.

Do czego prowadzi w świetle tej filozofii rzetelny wysiłek poznawania siebie? Odpowiedzią na to pytanie jest analiza egzystencjalnej postawy Sokratesa, z jaką spotykamy się na kartach Okruchów filozoficznych. Sokrates całe życie poszukuje prawdy o sobie, by umrzeć w wątpliwościach. Do końca nie potrafi rozstrzygnąć, kim właściwie jest: czy jest kimś bardziej podobnym do ,potwora Tyfona”, czy też do istoty, która „,z natury swej ma udział w czymś boskim"7. Bezwzględna uczciwość względem siebie każe mu zanegować każdą

7 Okruchy, s. 44. 
wiedzę, która nie wytrzymuje krytyki, lecz jednocześnie nie doprowadza go do jakiejś ostatecznej prawdy. Na tym polega właściwie dramat greckiego myśliciela. Ciągle na nowo poznając siebie, nie osiąga nigdy zadawalającego poznania. Niemożność dotarcia do jakiejś ostatecznej i niepodważalnej wiedzy o sobie jest zarazem doświadczeniem granicy swego myślenia. Sokrates nie jest w stanie jej przekroczyć, ale jednocześnie ustawicznie się z nią zderza. Tę sytuację Kierkegaard nazwie „paradoksem rozumu"8. Paradoks nie jest tu rozumiany na sposób logiczny jako np. współwystępowanie dwóch zdań logicznych, wzajemnie wykluczających się. Paradoksalność jest w ogóle cechą myślenia Sokratesa. „Wyrazem najwyższego stopnia paradoksu myślenia jest chęć odkrycia czegoś, czego ono samo nie może pomyśleć"9. Pragnienie poznania siebie jest większe, niż możliwości takiego poznania. Nic więc dziwnego, że samodzielne poznanie siebie zawsze jest poznaniem „do pewnego stopnia"10, nigdy do końca. Co zatem skłania Sokratesa do podejmowania ciągle nowych wysiłków poznawczych?

Wedle Kierkegaarda istnieje w człowieku źródło wewnętrznej siły, której działanie wywołuje paradoks myślenia. Jest nią tzw. namiętność (Lidenskab) ducha. Kierkegaard charakteryzuje ją niewprost i w sposób dosyć enigmatyczny. „Najwyższa potencjalność (Potens) każdej namiętności zawsze jest pragnieniem swego własnego spełnienia (Undergang) ${ }^{11}$ i podobnie, najwyższą namiętnością rozumienia jest pragnienie zderzenia (Anstodet), chociaż w jakiś inny sposób zderzenie może stać się jej spełnieniem"12. Istnieje w sferze ducha ludzkiego jakaś wewnętrzna siła, namiętność, która domaga się spełnienia, jakiegoś duchowego nasycenia, wypełnienia. Jeśli nawet w danej chwili nie przejawia się w pełni, to tkwi gdzieś w zarodku, niejako in potentia, stanowi ukrytą siłę, która poniekąd wyznacza cel do spełnienia. Człowiek pragnie do końca rozumieć siebie i to bynajmniej nie w znaczeniu teoretycznym, czysto oglądowym, lecz w znaczeniu praktycznym. Kierkegaard wyraźnie wskazuje na tę dwuznaczność rozumienia. „Rozumieć to, co się mówi - pisze w Pojęciu lęku — to jedno, rozumieć siebie samego w tym, co wypowiedziane, to druga rzecz"13. W tym przypadku nie chodzi o rozumienie znaczeń poszczególnych słów, wyrażeń, lecz o rozumienie w znaczeniu drugim. Najgłębszym duchowym pragnieniem człowieka jest przeniknięcie mroków swego istnienia, a zarazem udzielenie sobie odpowiedzi na pytanie: jak powinienem żyć. Człowiek

${ }^{8}$ Tamże, s. 47.

${ }^{9}$ Tamże, s. 44.

10 Papirer, $\mathrm{X}^{4} \mathrm{~A} 412$.

${ }^{11}$ Duński wyraz undergang tłumaczymy niedosłownie jako spetnienie. Wydaje się, że lepiej ono oddaje pierwotny sens oryginału niż zguba Toeplitza (por. Okruchy, s. 44). Natomiast włoski tłumacz Kierkegaarda używa tutaj określenia la fine (zob. S. Kierk ega a rd, Opere, Firenze 1972, s. 219).

12 S. Ki erkega ard, Philosophiske smuler. Samlede vaerker, B. 6, Copenhagen 1962 1964 , s. 38.

${ }_{13}$ Tenże, Begrebet angest, tamże, s. 223. 
musi odnaleźć obraz siebie w „tym, co wypowiedziane”, aby poprzez niego niejako przeglądając się w nim, jak w zwierciadle - mógł zrozumieć siebie. Lecz to najwyższe pragnienie rozumienia napotyka, czy też raczej zderza się z ograniczonymi możliwościami rozumienia siebie, z owym „do pewnego stopnia”, które jest właśnie iluzją, fałszem. Uczciwość Sokratesa polega na nieustannym negowaniu takiego częściowego samorozumienia i na jednoczesnym usiłowaniu przekroczenia tej granicy. Każda taka próba niesie z sobą doświadczenie istnienia tego, co nieznane. To, co nieznane nie daje się ująć pod postacią skończonej rzeczy, czy w ogóle czegoś określonego, skończonego. Kierkegaard umownie nazywa je Bogiem ${ }^{14}$. Jest to jednak zabieg formalny. Samo nadanie nazwy jakiemuś bliżej nieokreślonemu przedmiotowi niczego tu nie zmienia. Między nazwą „Bóg”, a nazwanym przedmiotem nie ma treściowego związku dotąd, dopóki pod nazwą nie dostrzega się określonego pojęcia, w tym przypadku, pojęcia Boga. Problem polega na tym, że „Bóg nie jest imieniem, lecz pojęciem"15.

Dla ludzkiej egzystencji znaczenie Boga nie objawia się wraz z doświadczaniem istnienia tego, co nieznane, lecz dopiero w momencie pojęciowego ujęcia tego, co doświadczane. Sytuacja poznawcza egzystującego nadal pozostaje paradoksalna. Przedstawienie Boga, jakie by ono nie było, jest dziełem konkretnej jednostki, to zaś, czego ono dotyczy jest „tym, co absolutnie różne"16. Aby wyrazić to, co niewyrażalne rozum sięga do arsenału własnych środków. Głównie do wyobraźni, która podsuwa przedstawienia Boga. Jeśli człowiek odnosi się do Boga, jako tego, co nieznane, poprzez mniej lub bardziej arbitralnie dobrane przedstawienia, wtedy rozum sam z siebie nie jest w stanie uchwycić różnicy między treścią własnego ujęcia, a tym, co doświadczane. Różność, która przylgnęła do rozumu, zmąciła jego jasność do tego stopnia, że nie zna on już sam siebie i konsekwentnie postępując, miesza siebie z tym, co odeń różne”. I dalej: „Rozum przybliżył się do Boga, jak tylko potrafił, i podobnie oddalił, jak tylko mógl"17.

Przyjęcie w konsekwencji czysto teoretycznego, spekulatywnego obrazu siebie i obrazu Boga nic nie daje. Jest to rozwiązanie sztuczne. Wedle Kierkegaarda, na taką ocenę zasługuje pomysł Platona, jako jednego z pierwszych twórców spekulatywnej prawdy o człowieku. Sądził on bowiem, że samopoznanie polega na przypominaniu sobie wiedzy wrodzonej. Platon zapomniał tym samym o egzystowaniu. Egzystowanie ściśle związane z samopoznaniem zanika jako proces na rzecz ostatecznego przyjęcia pewnej abstrakcyjnej wiedzy, która rzekomo ma odpowiadać wiedzy wrodzonej ${ }^{18}$. Pozór raz osiągniętej

\footnotetext{
14 Okruchy, s. 47.

15 Tamże, s. 49.

16 Tamże, s. 56.

17 Tamże, s. 54 n.

18 Afsluttende, B. 9 s. 172.
} 
prawdy unicestwia dalsze poszukiwania. Podobnie w odniesieniu do Boga. „Łatwiej i bezpieczniej podziwiać ideę, niż wierzyć w rzeczywistość”19. Na płaszczyźnie spekulatywnych rozważań łatwo zatem przyjąć jakąś mniej lub bardziej wydumaną prawdę o sobie i prawdę o Bogu. Z sokratejskiego (egzytencjalnego) punktu widzenia jest to samoułuda, pozór prawdy etycznej i religijnej. Ale z drugiej strony egzystencjalna sytuacja Sokratesa pełna jest niejasności. Nie sposób w niej odróżnić doświadczenia siebie od doświadczenia Boga. Kierkegaard powie, że w takiej sytuacji rzeczywistość etyczna zostaje „przeniknięta" rzeczywistością religijną ${ }^{20}$. Potrzebny jest zatem ktoś drugi, który by udzielił istotnej pomocy egzystującemu. Jeśli tym drugim ma być po prostu drugi człowiek, to w myśl poprzednich ustaleń mógłby się on zachować w dwojaki sposób. W pierwszym przypadku, podobnie jak Platon, proponowałby jakieś spekulatywne rozwiązanie, w drugim natomiast przyjąłby rolę majeuty. Rolą tego ostatniego jest poznawcze podprowadzanie np. poprzez odpowiednie stawianie pytań. Nie do niego natomiast należy udzielanie istotnych dla egzystującego odpowiedzi. Odpadają zatem obydwie możliwości.

Tym drugim może zatem być tylko Bóg. Bóg rozumiany jako pewna rzeczywistość, która nie ma nic wspólnego z pojęciem wymyślonym przez egzystującego. Człowiek nie może oczekiwać pomocy od czegoś, co sam wymyślił. Jeśli jest ktoś taki, kto poinformowałby go o istotnej różnicy, jaka zachodzi między nim, a Bogiem, to musi to być Bóg, który rzeczywiście istnieje niezależnie od ludzkiej świadomości ${ }^{21}$. Ponieważ filozoficzne dowodzenie nie wykracza poza immanencję myślenia, egzystujący winien obrać inny sposób, aby dotknąć Boskiej rzeczywistości. Według Kierkegaarda dostępna jest ona w szczególnym rodzaju duchowej namiętności, która nosi nazwę wiary ${ }^{22}$. Człowiek wierzący „rezygnuje z aspiracji rozumu” i otwiera się na Boską rzeczywistość. Tym razem namiętność wiary nie utożsamia się z sokratejską namiętnością całkowitego samopoznania. Akt nie jest tylko aktem woli. Możliwy jest dopiero dzięki tzw. warunkowi wiary ${ }^{23}$. Istnieje Nauczyciel, który przekazuje swemu uczniowi warunek wiary. Dzięki temu ostatniemu sam Nauczyciel staje się dla wierzącego przedmiotem wiary ${ }^{24}$. Czym jest ów warunek wiary i w jaki sposób Bóg udziela go człowiekowi? W świetle różnych wypowiedzi Kierkegaarda odpowiedź na pierwsze pytanie rysuje się niecałkiem ostro, także drugie nastręcza trudności. W istocie Kierkegaard niewiele robi, aby rzecz uczynić jaśniejszą.

W Dziennikach nie spotykamy się z pojęciem „warunek wiary”. Wiele jednak wskazuje na to, że zastępuje je pojęcie „łaski”. Warunek wiary przekazuje

\footnotetext{
19 Papier, V A 35.

${ }^{20}$ Afsluttende, B. 10 s. 83.

21 Okruchy, s. 56.

22 Tamże, s. 71.

23 Tamże, s. 76 n.

24 Tamże, s. 75.
} 
Bóg, zarazem jest Człowiekiem ${ }^{25}$. Autor Okruchów jest konsekwentny. Jeśli między Bogiem, a człowiekiem zachodzi absolutna różnica, jest rzeczą jasną, że między nimi powinien znaleźć się pośrednik, który będzie jednocześnie Bogiem i Człowiekiem. Według Nowego Testamentu jest nim Jezus Chrystus ${ }^{26}$. Kierkegaarda jako teologa interesują głównie te wersety Nowego Testamentu, które ukazują Chrystusa najpierw jako Odkupiciela, potem jako Mistrza (Nauczyciela) ${ }^{27}$. Chrystus ,nie przyszedł na świat po to, by zostawić nam przykład (1 P 2,21) — pisze Kierkegaard - w ten sposób mielibyśmy Prawo i zasługę". Najpierw jest Zbawicielem, który pragnie zbawienia czlowieka, potem dopiero jest Wzorem do naśladowania, Idealnym Wzorem, od którego nasze życie odbiega „nieskończenie daleko”. Uświadomienie sobie tego dystansu powoduje, że człowiek uniża się, staje się skromny, wtedy Chrystus jest miłosierdziem i udziela łaski naśladującemu Go, pozostając jednocześnie Najwyższym Wzorem $^{28}$. Jeśli tak można rzec, Chrystus występuje wobec wierzącego w podwójnej roli: udzielającego łaski i Mistrza. Doświadczenie Chrystusa jako Boga jest doświadczeniem wewnętrznym, indywidualnym i niepowtarzalnym. Tylko w duchowym wnętrzu człowieka Bóg „może dać świadectwo o sobie”29. W obu rolach Chrystus „dany” jest jednostce czysto subiektywnie, co Kierkegaard wiele razy to podkreślał - nie poddaje się ujmowaniu w pojęciach i kategoriach. Bóg pojawia się w immanencji ludzkiej świadomości i jest „to jedyna racja i presumcja dla wszelkiej wiedzy o Bogu"30.

\section{Poznawalność istnienia Boga w dialektyce wiary}

Z tego, co zostało powiedziane, wynika dosyć jednoznacznie, że dla egzystującego realne istnienie Boga jest bezpośrednią daną świadomości. Świadomość ta nie pociąga za sobą określonego rozumienia Boga. Doświadczenie obecności Boga - jak można sądzić na podstawie skąpych wypowiedzi autora Dzienników - jest raczej niejasnym, pierwotnie słabo określonym odczuciem. Wiele wskazuje na to, że Kierkegaard nie wiązał z tymi danymi świadomości jakichś pierwotnych sensów, dających wiedzę o Bogu. U Kierkegaarda szeroko rozumiane myślenie (w takim kartezjańskim znaczeniu) jest w stosunku do owych pierwotnych odczuć czymś transcendentnym, a zarazem nadającym sens temu, co przeżyte (odczute). Wspomniane przedstawienia Boga są, by tak rzec, myślową odpowiedzią na to, co pierwotnie doświadczone.

25 Tamże.

${ }^{26}$ Tamże, s. $127-129$.

27 Papirer, $\mathrm{X}^{5} \mathrm{~A} 45$.

28 Tamże, X1 A 279.

${ }^{29}$ Zob. K. To e plitz, Problem egzystencji $i$ esencji $w$ filozofii Kierkegaarda, „Archiwum Historii Filozofii i Myśli Społecznej”17:1971 s. 372.

30 Papirer, II C 59. 
Najogólniej rzecz biorąc, można wskazać u Kierkegaarda na dwa źródła tych przedstawień. Bez wątpienia najważniejszym z nich jest Pismo św., które dla wierzącego jest „drogowskazem” w poznawaniu Boga ${ }^{31}$, lecz niemniej ważną rolę pełni jego wyobraźnia w najszerszym tego słowa znaczeniu. W Chorobie na śmierć określa się wyobraźnię (Phantasien) jako najbardziej podstawową, obok woli, zdolność ludzkiego ducha. W niej nabiera konkretnych i skończonych kształtów świat uczuć, woli i poznania. Ona tworzy przedstawienia, kategorie naukowe, projekty egzystencji itd. ${ }^{32}$ Oba te źródła poznania dają wiedzę syntetyczną. U Kierkegaarda istnienie Boga nie jest sprawą logicznej procedury, ale nie wynika również wprost $z$ doświadczenia wewnętrznego. Doświadczenie to samo z siebie jest ,ślepe” i nabiera sensu dopiero w świetle przyjętej wiedzy. Wiedza o Bogu, jaką człowiek zdoła posiąść, nigdy nie ma ostatecznego charakteru, lecz ważność chwilową, podporządkowaną tzw. dialektyce wiary. Aby zobaczyć złożoność relacji zachodzących między doświadczeniem a wiedzą o Bogu, przyjrzyjmy się, choć bardzo pobieżnie, dialektyce wiary.

Najkrócej daje się to wyrazić następująco: istotą dialektycznego stosunku jest to, że człowiek odnosi się do Boga na przemian: pozytywnie i negatywnie. Jest to proces dynamiczny, zmienny. Odniesienie negatywne jest doświadczeniem tego, co nieznane, nieograniczone, nieskończone. Jednostka porzuca wszelkie pojęcia, kategorie i „otwiera się” na Nieskończoność. Pozwala się Jej ogarnąć, pochłonąć. Otwarcie się jest duchowym trwaniem w Nieskończoności. Przysparza ono cierpienia, które towarzyszy porzucaniu tego, co skończone, ograniczone (a przez to zrozumiałe), na rzecz tego, co nieskończone, co poza wszelkim ludzkim rozumieniem. Dopóki człowiek trwa w Nieskończoności, dopóty nie może zająć wobec Niej aktywnej postawy. Nie wie bowiem, do czego się odnosi, brak mu przedstawienia przedmiotu odniesienia. Lecz gdy próbuje odtworzyć w myśleniu swój negatywny stosunek, popada w iluzję skończoności. Myślenie narzuca skończoną postać temu, co nieskończone. Jednostka odnosi się teraz pośrednio, poprzez przyjęte przedstawienie, do przedmiotu wiary, innymi słowy, odnosi się pozytywnie. W gruncie rzeczy takie pośrednie odnoszenie się jest iluzją. Człowiek intencjonalnie zwraca się do przedstawienia, czyniąc je przedmiotem swego zainteresowania i zapominając o właściwym przedmiocie wiary. $\mathrm{Z}$ drugiej strony, to że popada on w skończoność nie jest czymś niewłaściwym, lecz nawet czymś koniecznym, stanowi bowiem kolejną okazję do otwarcia się na Nieskończoność. Stąd wierzący (egzystujący) stoi zawsze wobec tzw. niepewności przedmiotowej, którą za wszelką cenę chce uczynić treścią dobrze określoną ${ }^{33}$. Dialektyka wiary zakłada ciągłe osiąganie stanu wiary i jednoczesną jego utracalność. Wedle jej zasad nikt nie może powiedzieć, że jest wierzącym, lecz że co najwyżej staje się nim.

31 Tamże, VIII ${ }^{1}$ A 50.

${ }^{32} \mathrm{~S}$. K i e r k e g a a r d, Choroba na śmierć, Warszawa 1982, s. 166 n.

${ }^{33}$ Afsluttende, B. 9 s. $72-74$. 
Podsumowując, wypada jeszcze raz podkreślić, że u Kierkegaarda teoretyczne dowodzenie istnienia Boga nie ma żadnego znaczenia, bowiem wierzący skazany jest w dialektyce wiary na ciągłe doświadczenie Boskiej rzeczywistości i na ciągle nowe, świeże rozumienie tego, co doświadczane. Jeśli chciałoby się tu użyć augustyńskiej formuły: credo, ut intelligam, to u autora Okruchów ma ono jedynie dialektyczne znaczenie, nie jest zaś, i nie może być, obiektywizacją tego, co przeżywane i rozumiane subiektywnie. W świetle kierkegaardiańskiej filozofii egzystencji traci znaczenie każdy ponadczasowy argument filozoficzny, traci również znaczenie cała filozofia Boga, na rzecz co najwyżej jakiejś metafilozofii, zajmującej się ogólnymi metodami opisu różnych egzystencjalnych postaw wobec Boga. W przeciwieństwie do Hegla, Kierkegaard doprowadza do radykalnego oddzielenia filozofii spekulatywnej od prób opisu fenomenu religijnego życia człowieka.

\section{KIERKEGAARD FACE AUX PREUVES PHILOSOPHIQUES DE L'EXISTENCE DE DIEU}

\section{Résumé}

L'histoire de la pensée européenne, à partir, pour le moins, de St. Augustin, compte plusieurs tentatives philosophiques de prouver l'existence de Dieu. Nous rencontrons aussi de nombreuses critiques de ces preuves. Søren Kierkegaard (1813-1885), philosophe et théologien danois, précurseur de l'existentialisme européen, en est un des critiques les plus intéressants.

La philosophie de l'homme élaborée par Kierkegaard, permet de voir au jour nouveau l'essence de liaison religieuse de l'homme avec Dieu. Entre autres elle distingue nettement l'expérience personnelle de Dieu de la représentation de Dieu (idee, notion, image etc.). De cette position Kierkegaard critique les preuves strictement spéculatives de l'éxistence de Dieu (p. ex. les voies de St. Thomas). Il le fait pourtant de façon peu systématique, plutôt fragmentaire, dans des textes différents (Fragments philosophiques, Post-scriptum non scientifique, Journaux intimes). L'intention de notre article est de présenter la synthèse des opinions de Kierkegaard et d'examiner ses idées en matière de leurs présuppositions.

Il résulte des analyses efféctuées que pour Kierkegaard les preuves philosophiques de l'existence de Dieu admettent chez celui qui raisonne la conviction personnelle que l'objet d'argumentation existe. Le philosophe démontre que sans cette conviction toute argumentation dans ce domaine est impossible. Par rapport á l'expérience originelle de Dieu la recherche des arguments purement théoriques est un procédé secondaire, de moindre importance et même engendrant de fausses opinions concernant la nature de Dieu. D'autre part Kierkegaard montre que dans le processus de la connaissance éthique et religieuse de soi-même il est impossible de distinguer nettement l'expérience de Dieu sans l'admission d'un savoir apriorique sur Dieu et sur l'homme, c'est-á-dire des 
vérités révélées de telle ou telle autre religion. Du point de vue de l'individu existant ce savoir a le caractère objectif et plutôt formel et ne se materialise que dans la subjectivité de l'individu existant de façon religieuse. Celui-ci toujours á nouveau, dans ainsi dite dialectique de la foi conçoit par sa raison le sens de l'expérience de Dieu. Pour le croyant Dieu est dialectiquement présent et le rapport entre l'éxpérience et le savoir de Dieu est dynamique, toujours changeant. Pour Kierkegaard tout arguement philosophique extra-temporel ainsi que la philosophie de Dieu perdent leur valeur au profit de la philosophie de l'existence qui s'occupe des méthodes générales de la description des attitudes existentielles envers Dieu. 